\title{
ORGANISATIONAL BEHAVIOUR CHANGE TOWARDS WASTE REUSE IN THE UK THIRD SECTOR
}

\author{
P. TAVRI, S. SAYCE \& V. HANDS \\ Kingston University, UK.
}

\begin{abstract}
This paper explores, through the medium of literature review and a single in-depth empirical study conducted over a 1-year period, the ways in which a third sector organisation (TSO) is engaging in reuse behaviour change. The paper forms part of a larger scale $\mathrm{PhD}$ research project examining the ways in which corporate bodies can be helped to implement the UK government's ambition to move up the so-called waste hierarchy from recycling to 'reuse and preparing for reuse' [1]. The paper starts by exploring the existing literature on current reuse practices, which both confirms that normative behaviour is concentrated on recycling and identifies TSOs as leading proactive stakeholders in promoting reuse behaviour, noting that the literature is generally limited to household waste. Therefore, the empirical research sought to understand and identify whether, and if so how, normative behaviour towards reuse can be developed both within TSOs and potentially their business supply chain network. The paper reports on a single TSO (the Selby Trust), studied through a process of engaged action research and testing a behaviour change theoretical framework developed by Tavri et al. [2]. The action research tested the theory that by building a process known as 'associative strength' [3, 4], motivation for organisational behaviour change can be developed and, over the short term at least, maintained. The results point to the possibility of the case being replicable across other TSOs and throughout the business supply chain.

Keywords: action research, associative strength, empirical study, normative behaviour, organisational behaviour change, Selby Trust, theoretical framework, third sector organisation, waste reuse.
\end{abstract}

\section{INTRODUCTION: THE NEED TO MOVE TOWARDS REUSE - A UK CONTEXT}

A brief history of waste [5] identifies that reuse is not a new practice; indeed repair and reuse were predominant until at least 1950, when initial waste collection and segregation started in the UK [6]. Reuse was often undertaken by women at home in their role as bricoleurs, a person like artist who creates using a diverse range of materials [7]. Even today, in countries where economic wealth is low, household waste is reused through both economic and non-economic cycles [8]. The proliferation of waste, it is argued, is associated with developed countries having strong consumer demand and powerful marketing skills [9]. The UK is one such example; it adheres to the waste directives made by the European Commission, which prescribes the outcome of waste regulation policy for the member states, but leaves the choice of the forms and methods for achieving the desired results up to national governments [10]. To counter the rise of environmental degradation since the 1980s, the UK government has taken a strategic and increasingly stringent approach to waste reduction and management measures aimed at changing behaviours [5].

The UK government's first measure, the Landfill Tax, was introduced in 1996 [5] and has been successful in reducing landfill. Since 2000, waste being sent to landfill has reduced by around 53\% [11]. It has also led to a change in behaviour, which has seen increased recycling [12]. Currently, around 250 Million Tonnes (Mt) of waste is produced every year in England and Wales, of which $50 \%$ (125 Mt) is recycled and $27 \%$ is produced by corporates. The remainder is still being landfilled, leading to loss of large quantities of valuable reusable materials [1]. 
The necessity to move up the waste hierarchy is evident in the figures developed by the Office for National statistics, which shows a $15 \%$ increase in consumption of resources since 2009 [13]. Additionally, there has been a drop in landfill capacity by around 200 million cubic meters over 14 years [11]. Baudrillard's 1998 [9] consumer society work argued that the rise in consumption is becoming parasitic upon the whole system; and one of the most economic ways to decrease consumption is to prolong the life of existing materials through repair and reuse. A move towards this is argued to provide opportunities in fulfilling the waste targets set by government in decreasing the consumption of resources and bring economic benefits [14]. For instance, government predictions show that trading unused electrical appliances and garments could contribute $£ 2$ bn to UK GDP [1]. Furthermore, redirecting resources by prolonging the life of materials led to recognition of the circular economy also referred as the smart economy [15]. The principal is to transform the linear extraction-use-throw away model of production and consumption to a circular one [16].

The above provides evidence of government desire to move away from recycling towards reuse. However, this brings tensions: government also wishes to support corporate growth [17] but success in reuse as currently measured will decrease consumption. This may, therefore, be at odds with corporate ambitions to create profit by stimulating consumption. The key, it is argued, is to identify solutions to this major disincentive.

One such key may be found through the use of Third Sector Organisations (TSOs) as proactive intermediaries in the reuse process. Policy measures allow industry to decide the most cost-effective means of achieving reuse [18]. However, DEFRA [19] has identified benefits from TSOs becoming involved in waste management. They are perceived as having a role in encouraging corporates to become more effective in reuse which, in turn, could lead to social, economic and environmental gains to both corporates and TSOs.

The paper now goes on to summarise the literature used to develop a theoretical argument for TSOs as a catalyst in stimulating changed behaviours for reuse. This is corroborated by a detailed study with a single TSO where change for reuse was instigated through action research. The theoretical framework called CEBA, that is, Communication (C), Engagement or action (E), Behavioural Maintenance (B) and Avoidance of the value action gap (A), was presented in a previous paper by Tavri et al. [2]. The theoretical framework (CEBA) is tested to understand the organisational structure and to identify potential areas that allow TSOs to be an effective intermediary in making reuse a normative behaviour.

\section{CURRENT REUSE PRACTICES AND THE ROLE OF THIRD SECTOR ORGANISATIONS}

The literature on waste behaviour in relation to waste recycling is extensive (see, e.g. [20-34] Oskamp, et al., 1991; Sitarz, 1994; Thogersen, 1997; Murray, 1999; Vlek, 2000; Barr, et al.,, 2001; Janette et al., 2003; Sharp \& Luckin, 2006; Tucker \& Douglas, 2006; Bulkeley \& Gregson, 2009; Cox et al., 2010; Fudge \& Peters, 2011; Zhang et al., 2011; Bortoleto et al., 2012; Dolan, 2012) but far less so in relation to waste reuse behaviour. Where such studies exist, they focus on household bulky waste reuse and implementation of the Waste Electrical and Electronic Equipment (WEEE) Directive (2002) (see, e.g. [35, 36] Khetriwal et al., 2009; Blass \& Geyer, 2010). The collective findings of the reuse literature share two common themes: first that Local Authorities (LAs) are acting as initiators in behaviour change relating to reuse and, second, that they often work in collaboration with local TSOs to promote reuse in relation to household waste. 
TSOs cover a wide range of organisations but are defined by the Government Cabinet Office as [1]: '... a diverse active and passionate sector. Organisations in the sector share common characteristics: non government, value driven and principally reinvest any financial surplus to further social, environmental or cultural objectives. The term encompasses voluntary and community organisations, charities, social enterprises, cooperatives and mutual, both large and small'. Also known as Non-Governmental Organisations, they provide an important role in achieving national objectives as they operate at the core of social and environmental change.

Upon examining the literature (Section 2.1) on the promotion of reuse, it became apparent that TSOs are concerned almost exclusively with the household waste sector. Within this sphere, they are providing substantial social, economical and environmental benefits to the community. Nevertheless, the studies also point to several gaps and barriers in enhancing reuse activities.

\subsection{UK reuse studies}

This section now explores the evidence base in relation to the role that TSOs play in promoting and facilitating reuse.

A study in 2007 [37] determining residents' level of satisfaction with bulky waste collection and reuse services in three different locations in the UK (Bath, Swindon and Portsmouth) targeted recycling officers, bulky waste collection managers, and household waste recycling centres (HWRCs) at council depots. It found that proximity to reuse centres was a crucial factor in encouraging households to use TSOs for bulky waste collection services. The study found that TSOs/charitable organisations struggle to run reuse schemes due to poor funding, which creates a barrier as households are conscious of cost. Therefore, little headway was made towards reuse in the areas. Working partnerships between TSOs, HWRCs and LAs were found to be unclear.

A 2008 study [38] that focused on bulky waste reuse considered cost-benefit analysis (CBA) as a means of analysing a TSO furniture reuse scheme in London. The research found that quantifiable evidence failed to provide a full picture of the reuse organisation's effectiveness with respect to social and economic value, and called for further research to establish the benefits of reuse organisations across LAs and statutory agencies. Despite policy support and the involvement of the TSO, the study found that social and educational barriers limited the success of the initiative.

A 2009 study [39] investigated the effectiveness of Furniture Reuse Organisations (FROs: including all TSOs working towards reuse) and their relationship with LAs, applied CBA, Life Cycle Assessment, Environment Impact Assessment and Social Impact Assessment as assessment tools. The results identified communication, information, location and knowledge dissemination as four critical factors in achieving greater reuse of bulky waste within households. The study also found that a lack of qualified expertise for testing and sorting bulky waste for reuse posed a further barrier.

A 2008 London Community Resource Network (LCRN) report [40] identified a study conducted by London Remade in 2006, which focused on reuse provision made available to residents by LAs in collaboration with TSOs. Based on responses from both TSOs and LAs, the common barriers identified were: lack of space, lack of funding and inadequate measuring and monitoring. As per the report [38], London has over 600 TSOs delivering reuse services but less than $10 \%$ of these measures or monitors their activities. Despite this, bulky waste diversion from landfill to reuse has increased by $73 \%$ in 3 years (2004-2007) leading 
to significant increases in the social and economical benefits to people in low-income groups. Currently, 11 London Boroughs have a reuse service agreement with local TSOs to provide collection services that reduce bulky waste and increase provision of reuse items for low-income groups.

DEFRA reported in 2009 [19] on the benefits of involving TSOs in LA waste management. They refer to a 2005 survey, which identified 1000 waste TSOs in England which diverted approximately 500,000 tonnes per annum from landfill, despite the majority of the TSOs being small, local operations. However, around $7 \%$ had income over $£ 1 \mathrm{~m}$ p.a. and $20 \%$ operated regionally and/or nationally. DEFRA evaluated the benefits of TSOs by using a Social Return On Investment method on five case study TSOs. The results showed that the case study TSOs linked closely to LA agendas around: environmental sustainability, local economy, wellbeing, tackling exclusion and promoting equality and stronger community. It also provided evidence of positive value generated at national and global levels including environmental benefits from reducing landfill disposal, reduced carbon emissions and reduced consumption of new goods. The research gave credible evidence that TSO reuse activities are recognised as creating additional value for local areas.

With the aim of evaluating the role of TSOs in managing discarded household furniture and appliances, a study in 2010 [41] collected data from 249 organisations in the UK using website analysis, site visits and interviews. The study found that the two major sources of reuse items are public donations and retailers. Around $76 \%$ of all items are redistributed to low-income groups. This study illustrated that reuse is a social benefit activity. Furthermore, the study identified location as being one of the most important factors in aiding both the collection and redistribution processes.

The Third Sector Research Centre report in 2012 [42] summarised the main characteristics of TSOs. It indicated that TSOs are most powerfully influencing bodies towards pro-environmental behaviour change. TSOs bring innovation, trust, proximity, collective nature and group-based characteristics among individuals and households. However, major barriers were identified; as a lack of expertise, knowledge around communication, awareness, space, funding and resources; an absence of measuring and monitoring and difficulties of engaging and scaling up.

A 2013 study [43] conducted by Surrey County Council collaborated through the Surrey Reuse Network with six charities who collect and donate good quality kitchen appliances and home furniture and sell them at affordable prices. In 2011/2012, these organisations collectively diverted over 22,000 household items from landfill to reuse, which saved approximately $£ 40,000$ in landfill tax and enabled over 100 volunteering opportunities and 10 people to gain full-time employment.

\section{DISCUSSION AND REUSE INTRODUCTION TO THE CASE STUDY}

The studies detailed above show that initiatives are already taking place within some LAs to work with TSOs to encourage households to move towards reuse, with consequential social, economical and environmental benefits, which include reducing waste to landfill. These studies raise some interesting issues for the potential to further increase reuse in accordance with government policy and extend such initiatives to the corporate sector. However, although encouraging, the studies show that the potential of TSOs in changing behaviour towards reuse has been almost exclusively limited to the household level.

This research seeks to understand how TSOs can collaborate with corporate organisations to develop reuse as a normative behaviour among the business supply chain network. A 
previous paper by Tavri et al. [2] developed a theoretical framework (CEBA) based on an inductive analysis of environmental behaviour theories and this was tested in the empirical study detailed below. The framework identified Communication, Engagement/action, Behavioural maintenance and Avoidance of a value action gap (CEBA) as crucial factors for building 'associative strength' [3, 4] within organisations. Collier and Esteban [3] and Kong et al. [4] define associative strength as 'a willingness to change current behaviours due to a strong organisational identification that can translate into citizenship and cooperative type behaviour'. Furthermore, it is argued that associative strength is critical both in changing behaviour and importantly in maintaining it.

As an initial pilot study, the authors undertook a yearlong study of a single TSO (The Selby Trust) and worked with its staff and volunteers to enable them to analyse and evaluate their own reuse processes and review any economic benefits. It also aimed to assess whether change within this TSO could influence the supply chain and facilitate change for reuse there.

\section{EMPIRICAL STUDY OF A THIRD SECTOR ORGANISATION (TSO):} THE SELBY TRUST

The focus of the year long empirical study is The Selby Trust. It was set up as a charity in 1992 and is registered as a Social Enterprise and Community Incorporated Company. The term social enterprise is defined as '.. businesses which aim to achieve a social purpose. Often described as part of a third sector between the state and conventional private sector "for profit" businesses, their primary function is to meet their social aims' [44].

As part of their commitment to the environment, The Selby Trust has established four social enterprises that use 'green values' to promote recycling, waste reduction, energy efficiency and local skills for local communities. These social enterprises work for the social good with volunteers, the long-term unemployed and ex-offenders to make and restore furniture, other wood crafts, insulation and several other building materials to boost local skills and employment.

The Selby Trust is a small organisation (annual turnover: $£ 927,570$ in 2013-2014) located in a densely populated mixed commercial/residential area in North London. It was an ideal collaborative partner for the empirical study, as it was willing to develop and pilot a robust reuse system and related procedures, which they saw as an opportunity to explore the barriers they needed to overcome to improve success. For the researcher, this provided the ideal opportunity to test the theoretical framework (CEBA) within an organisation that appeared typical of small TSOs and facing the same barriers as those identified in the literature.

The main aim was to explore and understand organisational behaviour change and the translation of the theoretical stance on reuse into The Selby Trust reuse practice mechanisms. Action research is a research scenario in which the researcher provides expertise to guide the participants through a process [45]. During the researcher's intervention, care was taken to ensure ethical considerations were evaluated and all participants gave informed consent and were fully involved [45].

Overall, The Selby Trust considers itself to be 'opportunist' in regard to reuse and has undertaken informal business reuse activities with very limited success. In terms of its proximity to other local businesses and self-identified shortcomings, it is argued to be a fairly typical TSO. The major barriers to reuse were established through initial discussions with staff and were ones well-articulated in the literature. They included lack of expertise, knowledge and the absence of a measuring and monitoring system. It was acknowledged that the knowledge of the specific context is crucial to motivate organisational behaviour change [46]. 
Table 1 Stages overview

\begin{tabular}{|c|c|c|c|}
\hline Stages & Period & Activities & Purpose \\
\hline Stage 1 & Oct'13-Nov'13 & $\begin{array}{l}\text { Interview (Chief Executive } \\
\text { Officer \& Project Lead): } \\
1 \text { site visit }\end{array}$ & Baseline information \\
\hline Stage 2 & Dec'13 & 1 Site visit & Observations and notes \\
\hline Stage 3 & Jan'14 & Data analysis & Reuse inventory list \\
\hline Stage 4 & Feb'14 & $\begin{array}{l}\text { Group discussion (CEO, } \\
\text { Project Lead, Environmental } \\
\text { Manager \& Health and Safety } \\
\text { Officer): } 1 \text { site visit }\end{array}$ & $\begin{array}{l}\text { Presented the reuse plan } \\
\text { and developed reuse } \\
\text { system and procedure }\end{array}$ \\
\hline Stage 5 & March'14-Sep'14 & $\begin{array}{l}\text { Training, measuring and } \\
\text { monitoring and receiving } \\
\text { internal and external feedback } \\
\text { ( } 8 \text { site visits and email } \\
\text { correspondence) }\end{array}$ & $\begin{array}{l}\text { Training, feedback } \\
\text { and explored funding } \\
\text { opportunity }\end{array}$ \\
\hline Stage 6 & Oct'14 & $\begin{array}{l}\text { Final interview ( } 1 \text { site visit } \\
\text { and email correspondence) }\end{array}$ & $\begin{array}{l}\text { Revisit to explore reuse } \\
\text { behaviour change and } \\
\text { maintenance within } \\
\text { Selby and its business } \\
\text { supply chain }\end{array}$ \\
\hline
\end{tabular}

Section 5 provides an elaboration on the data collection process and analysis in carrying out the study. The study provided an understanding of the working environment of a TSO and at its final stage began to provide relationships with its business supply chain network. Furthermore, applying the theoretical framework (CEBA) to real-life reuse practice provided an initial evidence of behaviour change within the TSO and its business supply chain network and short-term maintenance over the course of the year of study.

\section{DATA COLLECTION}

In total over the year, 12 site visits were undertaken to have on-site induction, conduct interviews and hold group discussions with employees. Four staff employees (the Chief Executive, the Environmental Manager, the Project Lead and the Health \& Safety Officer) and two volunteers participated in the project. This represented 55\% of the staff employed. The interviews were conducted face to face and were set up at times convenient with staff involved, lasting on average $20 \mathrm{~min}$ each. The interviews and group discussions were used to develop an in-depth plan demonstrating the practical applications of the waste reuse strategy in the organisation. Table 1 provides an overview of activities elaborated (Sections 5.1-5.6) and conducted between October 2013 and October 2014.

\subsection{Stage 1}

The first stage in the process was to obtain baseline information to place activities within the theoretical framework (CEBA) developed by the researcher. Interview questions (Table 2) were formulated in compliance with the theoretical framework categories based on Commu- 
Table 2 Action research interview questions

\begin{tabular}{lll}
\hline Questions & Categories (CEBA) \\
\hline Q1 & $\begin{array}{l}\text { Does Selby Trust follow the current waste hierarchy? } \\
\text { Q2 }\end{array} \quad \begin{array}{l}\text { Do you have regulatory requirements (licenses, } \\
\text { exemptions, certificates)? }\end{array}$ & \\
Q3 & $\begin{array}{l}\text { Do you have internal and external regular feedback } \\
\text { systems in place? }\end{array}$ & Communication \\
Q4 & $\begin{array}{l}\text { Do you compare your reuse practice with competitors? } \\
\text { Q5 }\end{array} \quad \begin{array}{l}\text { Do you have reuse guidelines onsite for internal staff? } \\
\text { Q6 }\end{array} \quad \begin{array}{l}\text { Do you take any innovative measures in enhancing reuse? } \\
\text { Q7 }\end{array} \quad \begin{array}{l}\text { Do you have data or systems in place providing economic } \\
\text { and environmental value for reuse materials to measure }\end{array}$ \\
Q8 & $\begin{array}{l}\text { Do you measure internal and external qualitative and } \\
\text { quantitative benefits of reuse? }\end{array}$ & Engagement/action \\
Q9 & $\begin{array}{l}\text { Do you carry out any form of pre-assessment before } \\
\text { partnering with a business for reuse? }\end{array}$ & $\begin{array}{l}\text { Behavioural } \\
\text { maintenance }\end{array}$ \\
Q10 & $\begin{array}{l}\text { Do you carry out regular monitoring or audits on site? } \\
\text { How do you see the value action gap or misperceptions } \\
\text { among the staff and supply chain relating to reuse? Would } \\
\text { you say reuse is embedded with staff \& the supply chain? }\end{array}$ & $\begin{array}{l}\text { Avoidance of the } \\
\text { value action gap }\end{array}$ \\
\hline
\end{tabular}

nication, Engagement/action, Behavioural maintenance and Avoidance of value action gap (CEBA) and completed by the Chief Executive Officer (CEO) and the Project Lead. Next, a site visit was conducted, which revealed that The Selby Trust's 'Green Hub', which was established to undertake recycling, waste reduction and energy efficient projects, had also been involved informally in taking materials and seeking ways in which they could be reused and repaired. It also revealed that, in common with other TSOs, both staff and volunteers failed to conduct systematic monitoring and measuring of the materials on site and had little knowledge of the value and potential for reuse of the materials they collected.

\subsection{Stage 2}

Stage 2 utilised the results of the initial interview (Table 2) to set parameters for subsequent interviews, observations and group discussions; all of which were aimed at gaining detailed insight. A site map showing reuse locations was drawn up. These areas were observed to analyse reuse materials and produce evidence for how to assess both the environmental and economic value of the materials. Providing environmental factual information, which could lead to financial benefits or perceived satisfaction, has been argued to have substantial power to influence pro-environmental behaviour and maintain it $[47,48]$. Therefore, an inventory was produced of the existing reuse materials. 
Table 3 Inventory list

\begin{tabular}{|c|c|c|c|}
\hline $\begin{array}{l}\text { Types of } \\
\text { material }\end{array}$ & Description of material & $\begin{array}{c}\text { Estimated } \\
\text { embodied carbon of } \\
\text { product }\left(\mathrm{kg} \mathrm{CO}_{2}\right)\end{array}$ & $\begin{array}{l}\text { Estimated } \\
\text { cost }\end{array}$ \\
\hline Grade A wood & $\begin{array}{l}\text { Wood trunk and branches, wooden } \\
\text { logs, wooden beams, pallet slates, } \\
\text { wooden chips, wooden slates }\end{array}$ & 5111 & $£ 10,634$ \\
\hline Grade B wood & $\begin{array}{l}\text { Single panel door and timber } \\
\text { window frame }\end{array}$ & 505 & $£ 1250$ \\
\hline Grade C wood & $\begin{array}{l}\text { Wooden mobile drawers, laminate } \\
\text { wooden shelf, oak office table, } \\
\text { laminated timber paving slabs }\end{array}$ & 375 & $£ 1052$ \\
\hline Insulation & $\begin{array}{l}\text { Insulation slabs, insulation acoustic } \\
\text { tubes, wood insulation slabs }\end{array}$ & 1505 & $£ 5920$ \\
\hline $\begin{array}{l}\text { Building } \\
\text { materials }\end{array}$ & $\begin{array}{l}\text { Concrete slabs, bricks, concrete } \\
\text { blocks, plasterboard, insulated } \\
\text { plasterboard, steel lintels, steel cycle } \\
\text { hoops }\end{array}$ & 15,608 & $£ 15,789$ \\
\hline Miscellaneous & $\begin{array}{l}\text { Kitchen unit, kitchen worktop, } \\
\text { polyflor, vinyl flooring, floor } \\
\text { finishing, floor screedllatex, bags, } \\
\text { cartoons, nicobond tubs, friction } \\
\text { coat, radiator, ceramic tiles, cistern, } \\
\text { toilet pan, vinyl, paint }\end{array}$ & 7059 & $£ 8300$ \\
\hline Total & & $30,163 \mathrm{~kg} \mathrm{CO}_{2}$ & $£ 42,945$ \\
\hline
\end{tabular}

\subsection{Stage 3}

Using the Inventory of Carbon and Energy database developed by the University of Bath's Sustainable Energy Research Team [49] as a tool, the inventory of materials was analysed to calculate the estimated potential carbon savings, if reuse rather than recycling took place. Sources were then obtained through Google (www.google.co.uk) to determine the estimated cost of the materials as new, in order that The Selby Trust could finalise the discounted resale value. The resulting figures (Table 3 ) showed that a total of around 30 tonnes of estimated potential carbon savings $\left(\mathrm{CO}_{2}\right)$ and $£ 43,000$ worth of existing reusable materials had been accumulated at The Selby Trust. Whilst this sum may seem small, it was a 'quick win' of some $5 \%$ of The Selby Trust's annual income. The inventory primarily consisted of materials used within the construction and fitting-out process including everything from wood of various sizes and grades to toilet pans and office furniture.

\subsection{Stage 4}

Through group discussions with key staff (CEO, Project Lead, Environmental Manager and Health and Safety Officer), a reuse plan was introduced for the inventory (Table 3) and the 
steps to be considered for developing a robust reuse system and related procedures. A reuse process map, monitoring and measuring tools, action plan including targets and required legislative compliance were amongst the information provided. With agreement from key staff, the next step for the action research was to support The Selby Trust in implementing the reuse system and procedures including provision of training to ensure all staff members were able to properly catalogue incoming and outgoing reuse materials.

\subsection{Stage 5}

Implementation was carried out in accordance with staff availability for training, implementing the system and receiving feedback simultaneously. The reuse system and procedures involved steps to take reusable materials from businesses and to carry out regular internal inventory audits and monitoring. The researcher developed the required templates and tools such as a datasheet for recording the items, forms and signs for collection and distribution of reuse materials.

The initial evidence of reuse behaviour being embedded within the staff team was apparent in the latter half of this stage. The Selby Trust in partnership with the LA entered into the national Waste \& Resource Action Programme (WRAP); that is, Innovation in Waste Prevention Fund application. In comparison to the previous year (Stage 1), it was the first time that a formalised reuse system and procedure enabled them to enter into a grant.

WRAP is a registered charity and a limited company working with government, the EU and other funders to help deliver policies on waste prevention and resource efficiency. They take action in those areas where they can have the greatest impact on reducing waste, protecting natural resources and providing economical and environmental benefits (www.wrap.org). Although the Selby Trust did not receive any funding, during the process it succeeded in developing several business partnerships [the businesses that showed interest in partnership through positive feedback included: The HEET project, London Community Resource Network (LCRN), Retrofit Works Co-op, Leaner Logistics, Rubbishcut, ISG Plc (construction company), National Industrial Symbiosis Project (NISP), Forest Recycling Project (FRP), Restore Community Furniture, UK Wood Recycling Network, Irish Causeway, Bioregional, London Sustainability Exchange (LSx), Centre for Alternative Technology (CAT), Bricks and Bread Reuse Centre and UBM (media company)] through promoting its reuse system and procedures and ideas around reuse.

\subsection{Stage 6}

The final stage of data collection was a visit/interview 6 months after the plan had been implemented, in order to evaluate the changes that had been introduced both in terms of benefits to the business and the workforce. This was to assess whether the changes had been sustained or become normative in behavioural terms, and establish whether, even at this early stage, they hold impacted on the supply chain.

Reuse behaviour by The Selby Trust staff was evident amongst the workforce. They had gone on to develop a process focusing on market demand providing information on customers, suppliers, donors and reuse innovation goals. Enthusiastic feedback from some of the business supply chain network and their willingness to undertake reuse activities with The Selby Trust demonstrated an acceptance and maintenance of reuse behaviour at this initial stage. 


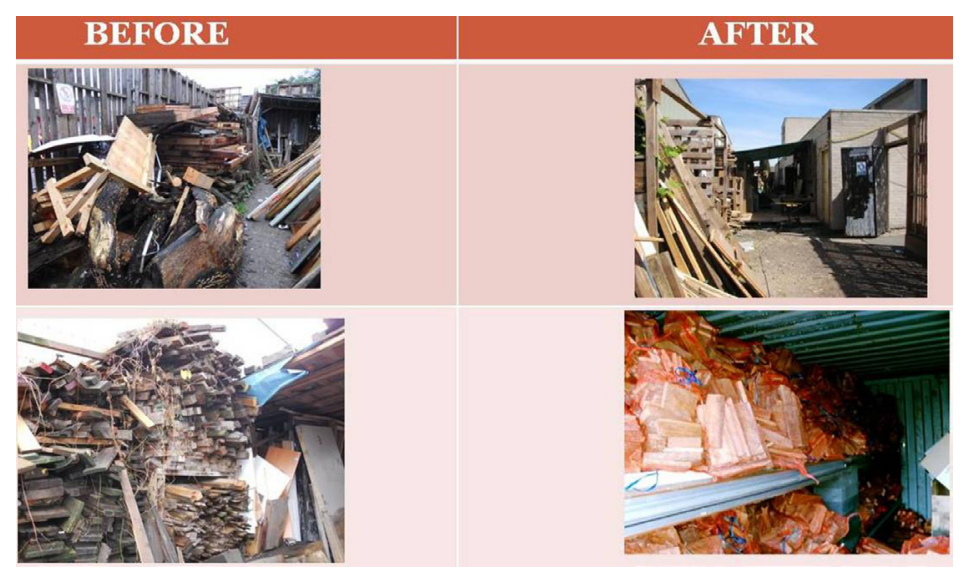

Figure 1: Before, the worksite was hard to access, dangerous and materials uncategorised. Since, a roof shelter has been provided, shelving and items are categorised and logged in an inventory and can be easily accessed for reuse.

\section{FINDINGS AND DISCUSSION}

The findings, accumulated from each stage of the work, provided clear evidence of reuse change being adopted. Through the iterative process of data collection, analysis and communication back to staff, The Selby Trust has succeeded in running more systemised reuse activities and thus able to maximise opportunities for reuse. The approach undertaken, which combined both the theory and the practice of reuse helped staff to make more sense of their own practical knowledge and experience to ensure reuse potential; it also helped to increase turnover by around $4 \%$. Furthermore, the action research provided The Selby Trust with clear, agreed, written guidelines and information on reuse and compliance with regulatory measures. This alerted them to contact the Environmental Agency to obtain the required licence and exemption certificates for the site.

The process of working with the staff and volunteers to systematise their work resulted in a much cleaner, tidier site (see Fig. 1) and a greater sense of purpose. The theoretical framework (CEBA) when applied to real-life reuse practice allowed time for staff engagement that enabled them to step back, reflect and implement new practices. It demonstrated that the theoretical framework (CEBA) appears to be applicable and reap useful information. It provide evidence of a change in behaviour towards reuse within The Selby Trust and its business supply chain and a simple theoretically based model for intervention which could be tested further elsewhere.

Theory indicates that such intervention effects tend to be short term [50]. The latter half of stage 5 and stage 6 of the project was given over to analysis and evaluation using training, emails and group discussions to judge the extent to which the changed reuse behaviours gave evidence of being embedded and maintained at this early stage. This does not mean that the associative strengths found to have been developed will necessarily be maintained for the long term. However, the early signs are that associative strength is sufficient to provide some level of confidence in sustained behaviour change.

To prove this, continued monitoring and observation is required. Within a one-year study timeframe The Selby Trust has shown a great enthusiasm by extending its reuse operation within its business supply chain that has provided positive feedback. Reuse is established as an organised ongoing practice at The Selby Trust and the positive feedback clearly indicates a change in reuse behaviour. 


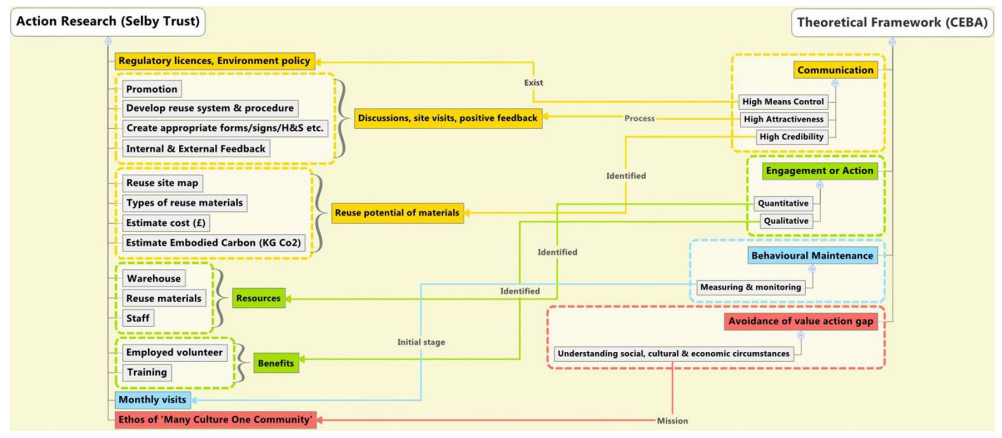

Figure 2: Tying back the framework to action research study.

The Selby Trust study also begins to validate the theoretical framework which argues that Communication, Engagement or action, Behavioural maintenance and Avoidance of the value action gap (CEBA) can change behaviour and can also initiate the transformation of changed behaviour into habit and normative behaviour (see Fig. 2).

\section{SUMMARY AND CONCLUSIONS}

The findings from the literature review identified that TSOs play a significant role in influencing and facilitating behaviour change in relation to normative household waste behaviour. However, many of the studies also pointed to common barriers to making reuse a normative behaviour. Lack of skills and knowledge combined with underfunding and weak measurement and monitoring are typical barriers to establishing a maintainable set of reuse behaviours. Nevertheless, whilst some successes within the field of household reuse behaviour were recorded in the literature, there has been little work focusing on TSOs in relation to their own reuse practices and their ability to influence the corporate sector positively.

The Selby Trust a TSO, which formed the focus of the empirical study, was keen to develop waste reuse systems and related procedures. The organisational goal to build reuse as a social enterprise developed an associative strength (cooperative type behaviour) among the staff members who were keen to understand the benefits of reuse and be supported to develop an action plan for implementing reuse.

Using action research as a methodology proved appropriate as its intent is to aid in resolving practical concerns for an organisation or people who are trying to deal with a problematic situation, assisted by the contribution of expert knowledge [51]. It made the study theoretically and practically viable, which benefited both the researcher and The Selby Trust which succeeded in developing reuse behaviour [46]. As a result of the action research, The Selby Trust put in place a reuse plan and process which is implemented on a day-to-day basis. Over the course of the one-year study, both the economic and non-economic benefits of reuse as a social enterprise activity at The Selby Trust were monitored.

Seeking to apply the theoretical framework (CEBA) to real-life reuse practice, it was found possible to draw out evidence that there were organisational barriers along the lines of those revealed by literature. Embedding reuse practice within existing roles in organisations takes time and may be subject to misperceptions. The provision of clear and consistent knowledge and information on reuse and explanations of the difference between reuse and recycling developed awareness amongst the staff. This confirms that knowledge regarding the specific context is crucial to motivate organisational behaviour change as found by Gamba and Oskamp [46]. 
The next stage of the research is to triangulate the results of the empirical study to the findings from a series of in-depth interviews with sustainability professionals from a range of organisations, including those down the supply chain from the Selby Trust as well as representatives from other TSOs. Follow up with Selby will also seek to evaluate how firmly have the changes been embedded and whether they are truly normative. The interviews aim to extract information on barriers and incentives and examples of organisational behaviour change for reuse and to introduce reuse as a normative behaviour in both corporate and TSO contexts. Although the theoretical framework (CEBA) covers the categories considered to be essential for organisational behaviour change and its maintenance and translation into normative behaviour, the interviews may identify other factors.

\section{REFERENCES}

[1] DEFRA, Waste Prevention Programme for England Call for Evidence (online), DEFRA: UK, 2013, available at https://www.gov.uk/government/consultations/callfor-evidence-waste-prevention-programme-for-england (accessed 25 April 2013).

[2] Tavri, P., Sayce, S. \& Hands, V., Developing a theoretical behavioural framework \& identifying its association with the UK industry evidence on waste reuse. WIT Transactions on Ecology and the Environment, 180, pp. 259-271, 2014. doi: http://dx.doi. org/10.2495/WM140221

[3] Collier, J. \& Esteban, R., Corporate social responsibility and employee commitment. Business Ethics: A European Review, 16(1), pp. 19-33, 2007. doi: http://dx.doi. org/10.1111/j.1467-8608.2006.00466.x

[4] Kong, N., Salzmann, O., Steger, U. \& Somers, A.I., Moving business/industry towards sustainable consumption: the role of NGOs. European Management Journal, 20(2), pp. 109-127, 2002.

[5] Waste Online, A History of Waste Management (online), The Environment Council, UK, 2004, available at http://wasteonline.brix.fatbeehive.com/resources/InformationSheets/HistoryofWaste.htm (accessed 12 February 2013).

[6] Castagna, A., Casagrande, M., Zeni, A., Girelli, E., Rada, E.C., Ragazzi, M. \& Apostol, T., 3R's from citizens point of view and their proposal from a case-study. UPB Scientific Bulletin, 75(4), pp. 253-264, 2013.

[7] Strasser, S., Waste and Want: A Social History of Trash, Henry Holt and Company, Macmillan: New York, 1999.

[8] Condon, D., Medley, K.E. \& Zhou, Y., Shared learning: feminist student research on household reuse behaviour. Journal of Geography, 105(5), pp. 209-215, 2006. doi: http://dx.doi.org/10.1080/00221340608978688

[9] Baudrillard, J., The Consumer Society Myths \& Structures, Sage Publications: London, 1998.

[10] Johnson, A., The Development of Waste Management Law (online). Available from ISWA Knowledgebase http://www.iswa.org/uploads/tx_iswaknowledgebase/538338_ Paper.pdf [accessed 26 June 2015]. http://www.coll.mpg.de/text/comparison-englishand-german-packaging-waste-management-law [accessed 22 August 2014].

[11] Environment Agency, Waste Data and Information, Environment Agency: UK (online), 2012, available from http://www.environment-agency.gov.uk/research/library/ data/34169.aspx.

[12] Resource Futures, Understanding Waste Growth at Local Authority Level, Resources Futures: Bristol, 2009.

[13] Office for National Statistics, Updated Estimates of UK Resource Use Using Raw Material Equivalents, Office for National Statistics: UK, 2013. 
[14] United Nations Sustainable Development, Agenda 21, United Nations Conference on Environment and Development, 3-14 June 1992, UNSD: Rio de Janerio, Brazil, 1992.

[15] Ellen Macarthur Foundation, Towards the Circular Economy, Vol. 1, Ellen Macarthur Foundation: UK, 2013.

[16] Ekstrom, K.M., Waste Management and Sustainable Consumption: Reflections on Consumer Waste, Routledge: Oxon, 2015.

[17] DEFRA, Business Waste Prevention Evidence Review: L1m1 - Technical Report, Brook Lyndhurst, Oakdene Hollins and Resource Recovery Forum: UK, 2011 (WR1403).

[18] Wilson, D.C., Stick or carrot? The use of policy measures to move waste management up the hierarchy. Waste Management \& Research, 14(4), pp. 385-398, 1996. doi: http:// dx.doi.org/10.1177/0734242X9601400406

[19] DEFRA, Benefits of Third Sector Involvement in Waste Management - Full Report, Resource for Change, NEF, Resource Futures: UK, 2009.

[20] Oskamp, S., Harrington, M.J., Edwards T.C., \& Sherwood, D.L., Factors Influencing Household Recycling Behaviour. Environment and Behaviour, 23, pp. 494-519, 1991. doi: http://dx.doi.org/10.1177/0013916591234005

[21] Sitarz, D., Agenda 21: The earth summit strategy to save our planet, Worldwatch environmental alert series, Boulder: EarthPress, 1994.

[22] Thogersen, J., Values and Attitudes Formation Towards Emerging Attitude Objects: From Recycling to General, Waste Minimization Behaviour. Advances in Consumer Research, 24, pp.182-189, 1997.

[23] Murray, R., Creating wealth from waste, London: Demos, 1999.

[24] Vlek,C., EssentialPsychology for Environmental Policy Making.International Journalof Psychology, 35(2), pp. 153-167, 2000. doi: http://dx.doi.org/10.1080/002075900399457

[25] Barr, S., Gilg, A.W., \& Ford, N.J., A conceptual framework for understanding and analyzing attitudes towards household-waste management. Environment and Planning A, 33, pp. 2025-2048, 2001. doi: http://dx.doi.org/10.1068/a33225

[26] Janette A., Ben C., Paul S. P., \& Adam D. R., Business excellence through resource efficiency (betre): An evaluation of the UKs highest recruiting facilitated self-help waste minimisation project. Resources, Conservation and Recycling, 38, pp. 271-299. id 319, 2003.

[27] Sharp, L., \& Luckin, D., The community waste sector and waste services in the UK: Current state and future prospects. Resources, Conservation and Recycling, 47, pp.277294, 2006. doi: http://dx.doi.org/10.1016/j.resconrec.2005.12.001

[28] Tucker, P., \& Douglas, P., Understanding household waste prevention behaviour. Scotland: University of Paisley Environmental Initiatives Research Group, (WRT109), 2006.

[29] Bulkeley, H. \& Gregson, N., Crossing the threshold: municipal waste policy and household waste generation. Environment and Planning, 41 (4), pp. 929-945, 2009. doi: http://dx.doi.org/10.1068/a40261

[30] Cox, J., Giorgi, S., Sharp, V., Strange, K., Wilson, D., \& Blakey, N., Household waste prevention - A review of evidence, The journal of the International Solid Wastes and Public Cleansing Association, 28(3), pp.193-219, 2010.

[31] Fudge, S., \& Peters, M., Behaviour Change in the UK Climate Debate: An assessment of Responsibility, Agency and Political Dimensions. Sustainability, 3, pp. 789-808, 2011. doi: http://dx.doi.org/10.3390/su3060789

[32] Zhang, N., Williams, I. D., Kemp, S., \& Smith, N. F., Greening academia: Developing sustainable waste management at Higher Education Institutions, Waste Management, 31 (7), pp. 1606-1616, 2011. doi: http://dx.doi.org/10.1016/j.wasman.2011.03.006 
[33] Bortoleto, A. P., Kurisu, K. H., \& Hanaki, K., Model development for household waste prevention behaviour. Waste Management, (0), 2012.

[34] Dolan, P., Hallsworth, M., Halpern, D., King, D., Metcalfe, R., \& Vlaev, I., Influencing behaviour: The mindspace way. Journal of Economic Psychology, 33, pp. 264-277, 2012. doi: http://dx.doi.org/10.1016/j.joep.2011.10.009

[35] Khetriwal, D.S., Kraeuchi, P., \& Widmer, R., Producer responsibility for e-waste management: Key issues for consideration- Learning from Swiss experience. Journal of Environmental Management, 90, pp.153-165, 2009. doi: http://dx.doi.org/10.1016/ j.jenvman.2007.08.019

[36] Blass, V.D., \& Geyer, R., The economics of cell phone reuse and recycling. Int $J$ Adv Manuf Technol. 47, pp. 515-525, 2010. doi: http://dx.doi.org/10.1007/s00170-009-2228-Z

[37] Curran, A., Heaven, S. \& Williams, I.D., Management of household bulky waste in England. Resource, Conservation and Recycling, 51, pp. 78-92, 2007. doi: http:// dx.doi.org/10.1016/j.resconrec.2006.08.003

[38] Alexander, C. \& Smaje, C., Evaluating third sector reuse organisations in the UK: casestudies and analysis of furniture reuse schemes. Resource, Conservation and Recycling, 52, pp. 719-730, 2008.

[39] Alexander, C., Curran, A., Smaje, C. \& Williams, I., Evaluation of bulky waste and reuse schemes in England. Waste and Resource Management, 162(WR3), pp. 141-150, 2009. doi: http://dx.doi.org/10.1680/warm.2009.162.3.141

[40] LCRN, Third Sector Reuse capacity in London, LCRN: London, 2008.

[41] Curran, A. \& Williams, I.D., The role of furniture and appliance reuse organisations in England and Wales. Resources, Conservation and Recycling, 54, pp. 692-703, 2010.

[42] Buchs, M., Edwards, R. \& Smith, G., Third Sector Organisations' Role in Pro-Environmental Behavior Change - A Review of the Literature and Evidence, TSRC: UK, 2012.

[43] Cottrell, H., Surrey Reuse Network (online), Surrey County Council: Surrey, 2013. Available from http://www.surreycc.gov.uk/environment-housing-and-planning/waste-andrecycling/ideas-to-reduce-your-waste/surrey-reuse-network [accessed 14 February 2013].

[44] Pattie, C. \& Johnston, R., How big is the big society? Parliamentary Affairs, 64(3), pp. 403-424, 2011. doi: http://dx.doi.org/10.1093/pa/gsr013

[45] Mills, J. \& Briks, M., Qualitative Methodology: A Practical Guide, London: Sage, 2014.

[46] Gamba, R.J. \& Oskamp, S., Factors influencing community residents' participation in commingled curbside recycling programs, Environment and Behaviour, 26, pp. 587 612, 1994. doi: http://dx.doi.org/10.1177/0013916594265001

[47] Cialdini, R.B., Crafting normative messages to protect the environment, Association for Psychological Science, 12, pp. 105-109, 2003. doi: http://dx.doi.org/10.1111/1467-8721.01242

[48] Rothman, A.J., Towards a theory-based analysis of behavioural maintenance, Health Psychology, 19(1), pp. 64-69, 2000. doi: http://dx.doi.org/10.1037/0278-6133.19.Suppl1.64

[49] Inventory of Carbon and Energy, Embodied Energy and carbon - The ICE Database (online), UK, 2011. Available from: http://www.circularecology.com/embodied-energyand-carbon-footprint-database.html\#.VinueX6rSUk [accessed 22 November 2012].

[50] Steg, L. \& Vlek, C., Encouraging pro-environmental behaviour: an integrative review and research agenda. Journal of Environmental Psychology, 29, pp. 309-317, 2009. doi: http://dx.doi.org/10.1016/j.jenvp.2008.10.004

[51] Bergold, J. \& Thomas, S., Participatory research methods: a methodological approach in motion. Forum: Qualitative Social Research, 13(1): 1, Art. 30, 2012. 